\title{
Considering Behind Limit Deformation for Calculation of Coal Pillars Parameters by Finite Element Method
}

\author{
Ermakova Inna.A. \\ T.F. Gorbachev Kuzbass State Technical University \\ Kemerovo, Russian Federation \\ inna-e@inbox.ru
}

\begin{abstract}
The paper presents the steps of calculating the stress-strain state of coal pillars by finite element method. The estimated area included the following blocks: the rock of roof and soil, coal pillar, broken-down rock, and the area of complete roof displacement. All the blocks were taken linearly deformable with natural deformation characteristics. The distribution of the bearing pressure on the pillar obtained on the first stage was used to determine the length of behind limit deformation zone and its deformation characteristics. On the second stage, the behind limit deformation zone was additionally calculated on the edge of the pillar. The analytical dependence of the length of the pillar's behind limit deformation zone (the distance to the maximum pressure) on the compressive strength of coal, depth and lateral thrust rate was established. This result allows us to find the minimum width of the stable pillars.
\end{abstract}

Keywords - coal pillars, finite element method, behind limit coal deformation, maximum bearing pressure.

\section{INTRODUCTION}

The calculation of the minimum width of the tape stable pillars is one of the main tasks of geomechanics in underground mining of minerals. Many works, a complete overview of which is given in [1], were devoted to the solution of this task.

The results of these studies are based on approximate solutions of elastic and elastic-plastic tasks of interaction of host rocks with pillars. In this paper, we develop a numerical approach based on the finite element method [2]. In contrast to [3-7], the stressed state of pillars is described with the help of full characteristics of coal compression diagrams.

At the present time, the complex of the most pressing issues that mining science faces now, such as development of mechanization of coal mining [8, 9], reducing aggressive impact of mining operations on the environment [10-14], design of organizational forms of coal enterprising [15-18], is supplemented with the problem of providing a world-class safety. Its main direction is researching the physical processes of coal extraction [19-21].

\section{MATERIALS AND METHODS}

The object of research was safety coal pillars of various purposes. To solve the problem of the possibility of pillars extracting, it was necessary to carry out the analysis of the

\author{
Pirieva Natalya.N. \\ JSC «SUEK-Kuzbass» \\ Leninsk-Kuznetzky, Russian Federation \\ PirievaNN@suek.ru
}

geomechanical condition and to set the size of the disturbed areas. The transition of pillar edge from the stable state into the broken one was taken into account in the consideration of behind limit coal deformation. To calculate the behind limit condition of the pillars edge, the finite element method was used.

\section{RESULTS AND DISCUSSION}

We reviewed the stress-strain state of coal pillars having different purpose: inter-face, under capital mine workings, under objects on the surface and underground.

The estimated rectangular area included the following units: coal pillar; mined-out area; host rocks; total displacement area (Figure 1). At the upper boundary of the calculating area $\mathrm{AB}$ there is no load (full surface). At the lower boundary $\mathrm{CD}$, remote from the pillar, there are no normal displacement (the border is secured). On the vertical borders $\mathrm{BC}$ and $\mathrm{AD}$ RMS there is lateral thrust strength acting.

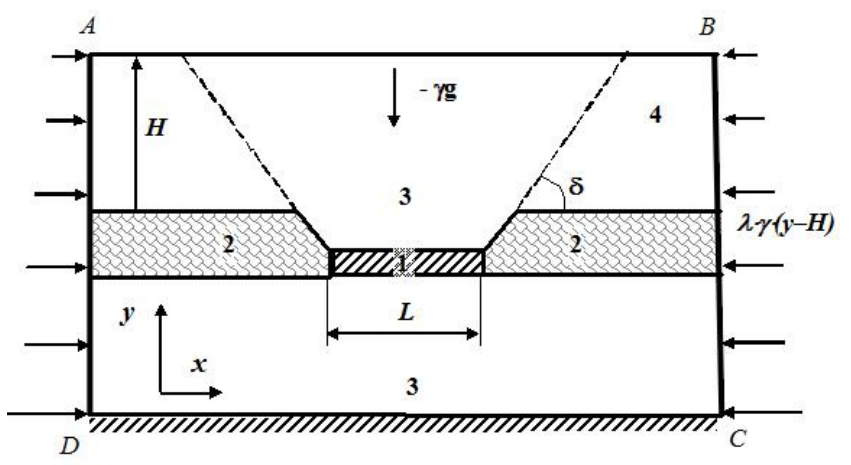

Figure 1. Calculation scheme: 1 - the coal pillar; 2 - caving of the rock; 3 - host rock; the area of full displacements

Coal pillar (1, Fig.1) is loaded with the volumetric force: $\gamma$ $=14000 \mathrm{~N} / \mathrm{m} 3, \mathrm{E}=109 \mathrm{~N} / \mathrm{m} 2$, Poisson ratio $v=0.25$.

The area of caved rock (2) is loaded with the volumetric force: $\gamma=20000 \mathrm{~N} / \mathrm{m} 3$, Young modulus $\mathrm{E}=108 \mathrm{~N} / \mathrm{m} 2$, Poisson ratio $v=0,25$. 
The block of host rock (3) is loaded with the volumetric force: $\gamma=25000 \mathrm{~N} / \mathrm{m} 3$, equal to the weight of host rock; Young modulus $\mathrm{E}=1010 \mathrm{~N} / \mathrm{m} 2$, Poisson ratio $v=0.25$.

The area of full displacements is loaded with the volumetric force: $\gamma=25000 \mathrm{~N} / \mathrm{m} 3$, Young modulus $\mathrm{E}=$ $0,5 \cdot 1010 \mathrm{~N} / \mathrm{Mm} 2$, Poisson ratio $v=0,25$.

Stage 1 of calculations. Stress-strain state of the calculating area is described by linear deformable blocks behavior. All the blocks are loaded by their own weight. The tasks were solved by finite element method (FEM) by the licensed program «ELCUT».

Vertical distribution of stresses in the pillar, roof strata and soil, as well as in the broken-down rocks is shown in Figure $2 \mathrm{a}$. In this figure, due to the symmetry of the task the left pillar, which borders the worked out area, is shown. Here, the compressive stress is negative and tensile - positive.

The distribution of vertical tensions $\sigma y y$ (the abutment pressure) on the edge of a pillar has the steadily declining character (Fig. 2b). The same steady decline is typical for vertical deformations of the pillar $-\varepsilon y$. At a certain distance $\mathrm{xm}$ from the edge of a pillar the normal tensions oyy reach their behind limit values for the compression $\sigma \mathrm{m}$. This value is defined by the following formula:

$$
\sigma_{m}=\frac{1-v}{v} \lambda \gamma H+\frac{\sigma_{s}}{1+v},
$$

where: $\mathrm{H}-$ the depth of development, $\gamma$ - specific weight of host rock, $\lambda$-the rate of horizontal thrust, $\sigma s-$ coal maximum strength for simple compression, $v$ - rate of sidereal deformation of coal.

At the same distance $\mathcal{X}_{m}$ compressive deformation of the pillar also reaches its behind limit value $\varepsilon_{m}$. Thus, in the interval $\left[0 ; x_{m}\right]$ the pillar is in unlimited condition accompanied with longitudinal fissures decreasing pillar's solids-carrying capacity. In the limiting point of the pillar with $x=0$, compressive deformation reaches its maximum, so $\varepsilon(0)=\varepsilon_{0}$ (Fig. 3 a). Due to this, the vertical tensions in the interval $\left[0 ; x_{m}\right]$ must be less than the behind limit value for compression strength $\sigma_{m}$. And for $x=0$ this tensions reach their minimum $\sigma(0)=\sigma_{0}$ in the edge segment. a)

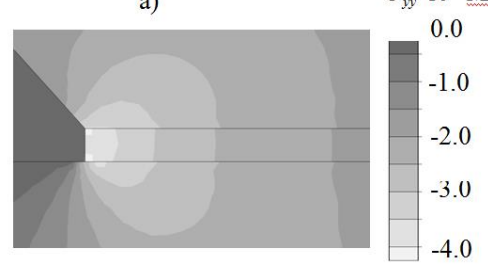

b)

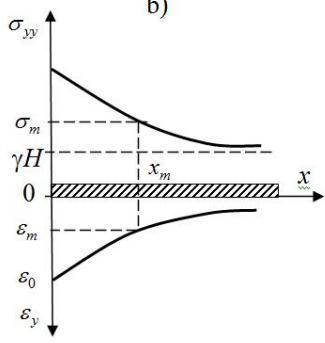

Fig. 2. The results of the calculation of array with linear deformations (a); the value of vertical stresses $\sigma_{y y}$ and vertical deformations $\varepsilon_{y}$ on the top of a pillar (b)
Here $\mathrm{M}$ is the module of ultimate deformations which equals the module of the linear deformation $\mathrm{E}$ for the fragile rock, so $\mathrm{M}=\mathrm{E}$. a)

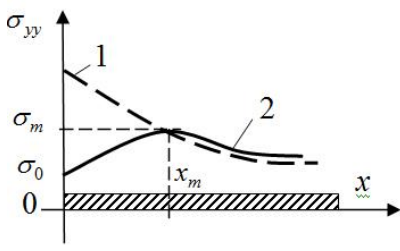

b)

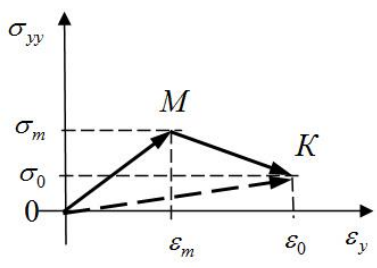

Fig. 3. a) Stress state of the pillar: 1 - for homogeneous pillar with linear deformation; 2 - with allowance for behind limit deformation; b) the diagram of pillar's deformation with

$$
x=0
$$

Compression process in the edge segment of a pillar is described by full diagram of coal volumetric compression. The OM part of the diagram describes simple deformation of coal up to the maximum strength $\sigma_{m}$ for the given strength mode. The MK part of the diagram describes simple deformation of coal but above maximum strength for the given strength mode.

Accordingly, full diagram of coal compression, the dependence connecting deformations and tensions above maximum strength has the following view:

$$
\sigma_{0}=\sigma_{m}-\left(\varepsilon_{0}-\varepsilon_{m}\right) \cdot M
$$

We suppose that stressed and deformed condition of the pillar with characteristics $\varepsilon 0$ and $\sigma 0$ can be reached under deformation of the edge segment of a pillar with a smaller module of the simple deformation E1. This hypothesis corresponds to the simple deformation of the pillar on the way $\mathrm{OK}$.

Stage 2 of calculations. The simple deformation module of caved spot of the pillar's edge can be defined from the following equation:

$E_{1}=\frac{\sigma_{0}}{\varepsilon_{0}}=\frac{\sigma_{m}-\left(\varepsilon_{0}-\varepsilon_{m}\right) \cdot E}{\varepsilon_{0}}=\frac{\frac{1-v}{v} \gamma H+\frac{\sigma_{s}}{1+v}-\left(\varepsilon_{0}-\varepsilon_{m}\right) \cdot E}{\varepsilon_{0}}$

The convergence value of pillars floor and top $u(0)=u_{0}$ in its limiting point $x=0$ with thickness of a seam $\mathrm{m}$ is defined as:

$$
u_{0}=\varepsilon_{0} \cdot m=\frac{\sigma_{0}}{E_{1}} \cdot m
$$

For behind limit pillar's deformation modeling, we set the caved zone of coal appears in the edge part of a pillar. The module of its deformation can be defined using (3). The length of this zone is equal to the distance to the maximum of bearing 
pressure $x_{m}$, and the vertical size is equal to the compressive value of the edge part of the pillar u0 (Fig. 4).

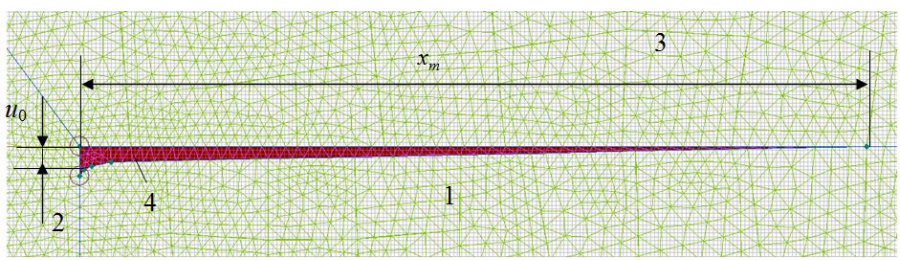

Fig. 4. The part of calculation area including the edge segment of a pillar: 1 - coal pillar; 2 - caved space; 3 - host rock;

4 -zone of coal with reduced modulus of linear deformation

The distribution of the vertical tensions in the pillar considering its behind limit deformations is shown on Fig. 5.

a)

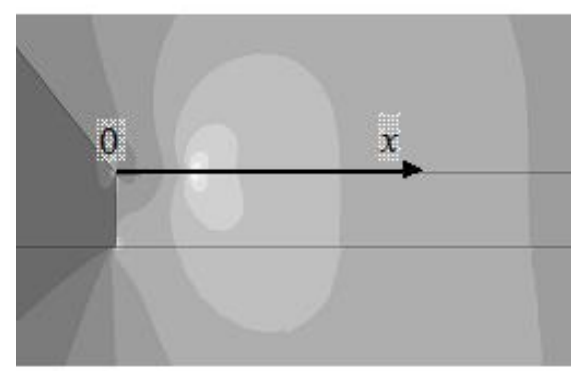

b)

Tense $\left(* 10^{7} \mathrm{~N} / \mathrm{m}^{2}\right)$

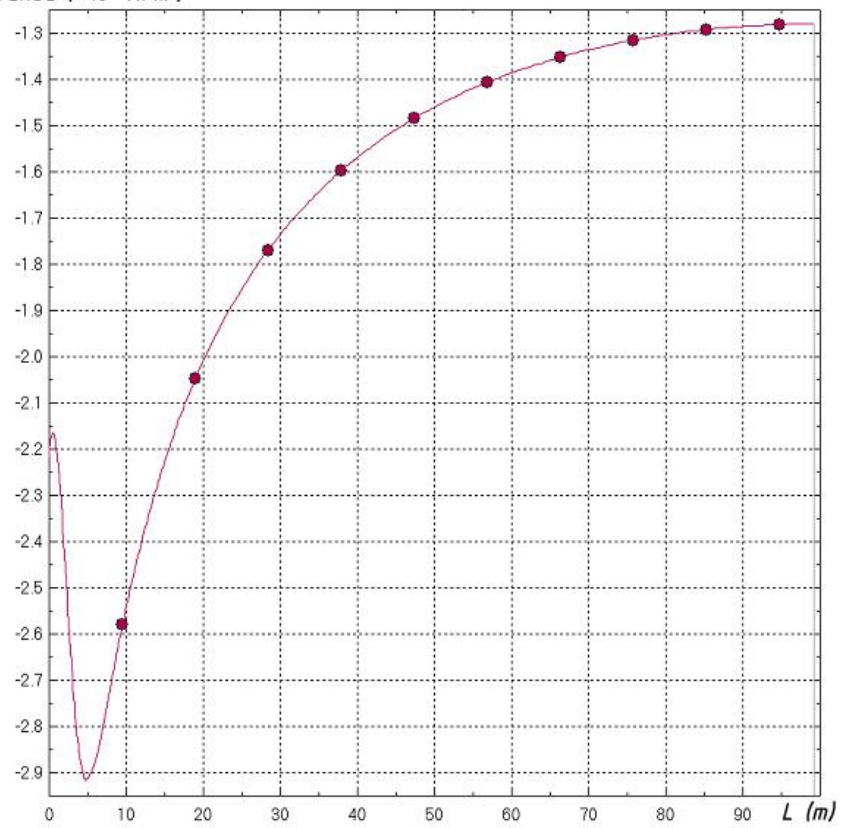

Fig. 5. The distribution of vertical strength in the pillar considers its behind limit deformation: a) in the array; b) on the top of a pillar
Digital experiments were conducted under the following conditions:

The maximum strength zone shifts to the solid array (Fig. $5 a)$, and on the diagram (5b) the maximum of the bearing pressure can be seen.

- the depth of development: $\mathrm{H}=200,300,400,500 \mathrm{M}$;

- the maximum strength of coal for simple compression: ${ }^{\sigma}{ }_{s}=8,10,12,14,16,18,20 \mathrm{MPa}$;

- bearing pressure rate: $\lambda=\frac{1}{3}, \frac{1}{2}, 1$.

So the common number of experiments was 84 .

The calculations conducted in this research allowed to set the dependence of the behind limit deformations zone length on the basic parameters in the following way:

$$
x_{m}=0.01465 \cdot \lambda^{-2.3456} \cdot H \cdot\left(\frac{\gamma H}{\sigma_{s}}\right)^{1.4541} \text {. }
$$

The determination dependence index (6) $\mathrm{R} 2=0.8958$, so the equation and all its rates are valid with level of confidence (error probability) less than 10-23.

Obtained dependence allows to estimate the pillar's minimal length in the steady conditions, as $L=2 \cdot x_{m}$.

\section{CONCLUSIONS}

1. The method of calculation of stress-strain state of the pillar by the finite element method considering its behind limit deformation was developed.

2. The dependence of the zone length of pillar behind limit deformation (the distance to the pressure maximum) from the depth, coal simple compression strength and the coefficient of lateral thrust was obtained.

3. It is proposed to use the developed methodology of assessing geomechanical state of pillars under mine workings in the mines of JSC "SUEK-Kuzbass".

\section{REFERENCES}

[1] Lin'kov A.M. On the Theory of Pillar Design. Journal of Mining Science, 2001, 37(1), pp. 10-28.

[2] Zienkiewicz O.C., Taylor R.L., and Zhu J.Z. The Finite Element Method: Its Basis and Fundamentals (7th Edition). ButterworthHeinemann, 2013,756 p.

[3] Seryakov V.M. Calculation of stress-strain state for an over-goaf rock mass. Journal of Mining Science, 2009, 45(5), pp. 420-426.

[4] Dyagileva A.V., Gogolin V.A., and Ermakova I.A. Napryazhennoe sostoyanie ugol'nykh plastov slozhnoy struktury pri ochistnoy vyemke [The stress state of coal seams of complex structure with the producting works]. Gornyy informatsionno-analiticheskiy byulleten' (nauchno-tekhnicheskiy zhurnal), 2011, vol. 6, pp. 13-17. 
[5] Kornev E.S., Pavlova L.D., and Fryanov V.N. Chislennoe modelirovanie geomekhanicheskogo sostoyaniya geomassiva pri dvustoronney vyemke korotkikh ugol'nykh stolbov. [Numerical modeling of rock massif geomechanical condition with bilateral notch short of coal pillars]. Vestnik Kuzbasskogo gosudarstvennogo tehnicheskogo universiteta, 2015, vol. 2, pp. 20-25.

[6] Kornev E.S., Pavlova L.D., and Fryanov V.N.. Razrabotka kompleksa problemno-orientirovannykh programm dlya modelirovaniya geomekhanicheskikh protsessov metodom konechnykh elementov [Development of the problem-oriented programs complex for modeling of geomechanical processes by finite element method] Vestnik Kuzbasskogo gosudarstvennogo tehnicheskogo universiteta, 2013, vol. 2, pp. 65-69.

[7] Kurlenya M.V., Mirenkov V.E., and Shutov V.A. Rock deformation around stopes at deep levels. Journal of Mining Science, 2014, 50(6), pp. 1001-1007.

[8] Khoreshok A. On side cutting bit when operating at sheerer drums. Ugol', 2002, vol. 7, pp. 10-11.

[9] Aksenov V.V., Khoreshok A.A. and Beglyakov V.Yu. Justification of creation of an external propulsor for multipurpose shield-type heading machine - GEO-WALKER. Applied Mechanics and Materials, 2013, vol. 379 , pp. $20-23$

[10] Lesin Y.V., Lukyanova S.Y. and Tyulenev M.A. Mass transfer of dispersed particles in water filtration in macro-grained media. Journal of Mining Science, 2010, 46(1), pp. 78-81.

[11] Tyulenev M, Zhironkin S., Kolotov K. and Garina E. Background of innovative platform for substitution of quarry water purifying technology. Pollution Research, 2016, 35(2). pp. 221-226.

[12] Tyulenev M.A. and Lesin Y.V. Justification complex purification technology open-pit mines wastewater. Taishan Academic Forum Project on Mine Disaster Prevention and Control, 2014, pp. 441-444.
[13] Lesin Y.V., Luk'yanova S.Y. and Tyulenev M.A. Formation of the composition and properties of dumps on the open-pit mines of Kuzbass. IOP Conference Series: Materials Science and Engineering. 2015. vol. 91(1), 012093.

[14] Tyulenev M, Zhironkin S. and Litvin O. The low-cost technology of quarry water purifying using the artificial filters of overburden rock. Pollution Research, 2015, 34(4). pp. 825-830.

[15] Zhironkin S.A. Governmental factoring development of TEK Kuzbass. Ugol', 2001, vol. 6, pp. 62.

[16] Zhironkin S.A. Prospects and new possibilities investment attracting to Kuzbass coal mining industry, Ugol', 2002, vol. 6, pp. 31-36.

[17] Zhironkin S.A. Factoring and leasing development at coal mining industry of Kuzbass as an important element of its financial part. Ugol', 2001, vol. 4, pp. 29-30.

[18] Zhironkin S.A. About measures of vexel circulation development and vexelability definition of fuel-and-power complex' enterprises. Ugol', 2002, vol. 4, pp. 47-48.

[19] Ryzhkov Y.A., Gogolin V.A., and Karpenko N.V. Modelling the structure of solid masses of lump and granular materials (plane problem). Journal of Mining Science, 1992, 28(1), pp. 6-12.

[20] Ryzhkov Y.A., Lesin Y.V., Gogolin V.A., and Karpenko N.V. Modeling the structure of fragmented and granular material: Threedimensional problem. Journal of Mining Science, 1996, 32(3), pp. 188-191.

[21] Gogolin V. A., and Ryzhkov Yu. A. A nonlinear model of the interaction between the side rocks, the stowage material, and the coal seam. Soviet Mining Science, 1977, 13(1), pp. 17-20. 